\title{
EFFECT OF DIFFERENT LEVELS OF WATER DEFICIT ON RAPESEED (Brassica napus L.) CROP
}

\author{
Efeito de diferentes níveis de déficit hídrico na cultura da canola
}

\author{
Carolina Bilibio $^{1}$, Jacinto de Assunção Carvalho² Oliver Hensel $^{3}$, Uwe Richter ${ }^{3}$
}

\begin{abstract}
Effects of different levels of water deficit applied during rapeseed crop development were assessed in a trial with metallic pots in greenhouse at the Department of Agricultural Engineering of Kassel University, Witzenhausen, Germany. A randomized block design was used with one cultivar (Ability Summer Rape) and three levels of water deficit $(0,30$, and $60 \%$ of evapotranspiration) in three treatments and 20 replicates. Irrigation management was carried out through daily water balance, where ET = I $-\mathrm{D}$; ET: evapotranspiration; I: irrigation; and D: drainage. The following evaluations were carried out weekly: stem diameter (mm); plant height $(\mathrm{cm})$; number of leaves; number of branches and number of pods. At the end of the experiment, assessed total green matter ( $\mathrm{g}$ plant $\left.{ }^{-1}\right)$, total dry matter $\left(\mathrm{g} \mathrm{plant}^{-1}\right)$, grain yield $\left(\mathrm{g} \mathrm{plant}^{-1}\right)$, grain protein content $(\%)$ and grain oil content $(\%)$ were also assessed. Data were submitted to variance analysis and the effect of the treatments was assessed by regression analysis. Results showed significant differences between the treatments in all analysed variables except for plant height and grain protein content, by test $\mathrm{F}$ at $5 \%$ probability. Factor of response ky, indicator of crop sensitivity to water deficit, was lower than one for all assessed variables. Grain yield showed the highest sensitivity to water deficit.
\end{abstract}

Index terms: Water management, irrigation, water deficit.

\section{RESUMO}

Os efeitos de diferentes níveis de déficit hídrico, aplicados durante o desenvolvimento da canola, foram avaliados por meio de um experimento conduzido em vasos de metal no interior de uma casa de vegetação, no Departamento de Engenharia Agrícola, da Universidade de Kassel, Alemanha. Foi utilizado um delineamento inteiramente casualizado, com a cultivar Ability (Summer Rape), e três níveis de déficit de água, $0 \%, 30 \%, 60 \%$ da evapotranspiração da cultura, totalizando três tratamentos com 20 repetições. O manejo da irrigação foi realizado por meio do balanço hídrico diário, em que ET = I - D, onde ET é evapotranspiração, I é irrigação, D é drenagem. Foram realizadas semanalmente as seguintes avaliações: diâmetro do caule $(\mathrm{mm})$, altura da planta $(\mathrm{cm})$, número de folhas, número de ramos e número de síliquas. No final do experimento, foram avaliadas a matéria verde total $\left(\mathrm{g} \mathrm{planta}^{-1}\right)$ e matéria seca total $\left(\right.$ g planta $\left.^{-1}\right)$, produtividade de grãos $\left(\mathrm{g} \mathrm{planta}^{-1}\right)$, além do teor de proteína $(\%)$ e de óleo $(\%)$ dos grãos. Os dados foram submetidos à análise de variância, sendo o efeito dos tratamentos estudado por meio de análise de regressão. Os resultados mostraram diferenças significativas entre os tratamentos para as variáveis analisadas, exceto para a altura das plantas e teor de proteína dos grãos, pelo teste $\mathrm{F}$ a $5 \%$ de probabilidade. $\mathrm{O}$ fator de resposta ky, indicador da sensibilidade da cultura ao déficit hídrico, foi menor que um para todos os parâmetros estudados. A produtividade de grãos apresentou a maior sensibilidade ao déficit hídrico.

Termos para indexação: Manejo de água, irrigação, déficit hídrico.

(Received in july 18, 2010 and approved in march 22, 2011)

\section{INTRODUCTION}

Water shortage in some regions of the world (RIJSBERMAN, 2006; KHAN et al., 2009) definitely increases interest in carrying out studies on development of crops showing acceptable yield under water deficit (ZWART; BASTIAANSSEN, 2004; FARRE; FACI, 2006; PAYERO et al., 2006; SINAKI et al., 2007). Understanding the behaviour of every crop, regarding different amounts of applied water, is absolutely necessary to determine when lack or excess of water may cause production fall, thus enabling appropriate irrigation management (BERNARDO et al., 2006).
Local studies on the relationship between fall of relative yield and relative deficit of evapotranspiration are recommended (GEERTS; RAES, 2009), as production conditions during crop cycle depend on the place and variety chosen (DOORENBOS; KASSAN, 1994).

Deficit irrigation is performed differently from supplementary irrigation, as in deficit irrigation we reduce depth of application while irrigation frequency is maintained. Supplementary irrigation aims at meeting crop water requirements during critical development stages without natural precipitation (ZHANG et al., 2006).

\footnotetext{
${ }^{1}$ University of Kassel/Unikassel - Department of Agricultural Engineering - Nordbahnhofstr - 1 a - Witzenhausen - 37213 - Germany bilibio@uni-kassel.de

${ }^{2}$ Federal University of Lavras/UFLA - Department of Agricultural Engineering - Lavras, MG

3University of Kassel/Unikassel - Department of Agricultural Engineering - Germany
} 
Deficit irrigation does not always decrease yield, as deficit properly applied in some development stages may even increase crop yield. Many research studies have been carried out to verify the effect of water deficit on crops (DETAR, 2008; GEERTS; RAES, 2009).

Farre e Faci (2006) compared corn (Zea mays L.) and sorghum [Sorghum bicolor (L.) Moench] response to water deficit through an experiment carried out in northeastern Spain. Plant vegetative part, total biomass and grain yield were affected by the treatments in both crops. Corn grain yield was higher than sorghum grain yield under optimum irrigation conditions, although sorghum showed higher yield under moderate or severe water deficit. The authors concluded that sorghum could be a good alternative to replace corn under limited water supply in the semi arid north-eastern Spain.

Sinaki et al. (2007) assessed rapeseed response to different levels of groundwater depletion equivalent to $20 \%, 50 \%$ and $75 \%$ of water available in soil concluding that, among yield compounds, number of pods was the most sensitive to water deficit.

The objective of this study was to assess the effect of different levels of water deficit applied during rapeseed crop development on vegetative parameters, grain yield, grain protein content and grain oil content of rapeseed, Hybrid Ability.

\section{MATERIAL AND METHODS}

The experiment was carried out in acclimatised greenhouse at the Department of Agricultural Engineering of Kassel University, Witzenhausen, Germany. A meteorological station inside the greenhouse monitored environmental conditions concerning temperature and relative air humidity.

Soil used for pot fulfilment was extracted from subsurface layer until $20 \mathrm{~cm}$ depth, and samples were collected for physical and chemical analyses. Soil was airdried, broken into small pieces and sieved through a $1 \mathrm{~cm}$ mesh. Pots were set on metal bench. A mixture was made with $80 \%$ of soil from the field and $20 \%$ of sand, in order to facilitate irrigation management. Granulometric analysis of prepared soil showed the following rates: sand: $32.37 \%$; silt: $53.76 \%$; clay: $13.88 \%$.

Fertilization used $4 \mathrm{~g} \mathrm{pot}^{-1}$ with concentration of $7 \%$ nitrogen; $6 \%$ phosphorus; and $10 \%$ potassium. Later we performed fertilization with nitrogen cover, using $1 \mathrm{~g}$ pot $^{-1}$ of urea diluted in water to meet the nutrient dose of $150 \mathrm{~kg} \mathrm{ha}^{-1}$ nitrogen recommended by Cordeiro et al. (1993) and Tomm (2007).
We used randomized block design with three treatments and 20 repetitions, corresponding to three levels of water deficit, $0 \%, 30 \%, 60 \%$ of crop evapotranspiration, amounting to 60 experimental units. Hybrid Ability, widely grown in Germany, was sowed in $6.5 \mathrm{dm}^{3}$ capacity metallic pots (Mitscherlich-Gefäßen) on 7 April 2009, in $0.02 \mathrm{~m}$ depth, with 10 seeds per pot. Later we carried out pruning to adjust one plant pot $^{-1}$. It was necessary to tutor plants with bamboo stakes in order to keep plants from falling over. Weed and disease were controlled according to need, in continuous monitoring.

We assessed vegetative parameters, productive parameters and grain quality from all experimental units, 60 crops. As treatments started we assessed stem diameter $(\mathrm{mm})$ with digital pachymeter; plant height $(\mathrm{cm})$ with tape measure; number of leaves plant ${ }^{-1}$; number of branches plant $^{-1}$ and number of pods plant ${ }^{-1}$ on a weekly basis.

Total dry matter (grams plant ${ }^{-1}$ ) was assessed at the end of the experiment in forced ventilated oven at $105^{\circ} \mathrm{C}$ (WANG et al., 2007; ARABHOSSEINI et al., 2009), where plants were kept during 24 hours. Total green matter (grams plant $^{-1}$ ) was assessed through weighing of leaves, branches and pods in electronic scale. Leaves were collected daily according to their natural senescence. Afterwards, they were weighed and stored in paper bags to assess dry matter.

Harvest was carried out manually when pod grain colour of the central part turned brown. Oil content (\%) and protein content (\%) of grains of each experimental unit were assessed at the specialised laboratory Landesbetrieb Hessisches Landeslabor, in Kassel, Germany.

Quantification of water deficit effect on yield was achieved with the relationship between relative decrease of grain yield and relative decrease of evapotranspiration, given by the coefficient of response ky (Doorenbos e Kassan, 1994), according to Equation 1:

$$
\left(1-\frac{Y r}{Y m}\right)=K y\left(1-\frac{E T r}{E T m}\right)
$$

in which: $\mathrm{Yr}$ - real yield; $\mathrm{Ym}$ - potential yield; $\mathrm{Ky}$ - crop coefficient of response; $\mathrm{ETr}$ - real evapotranspiration and ETm - potential evapotranspiration.

Potential yield (Ym) and potential evapotranspiration (ETm) were obtained in the treatments corresponding to $0 \%$ of water deficit, whereas real yield (Yr) and real evapotranspiration (ETr) were found in the other treatments.

All assessed parameters were submitted to analysis of variance by $\mathrm{F}$ test, significant at $5 \%$ probability, while 
Tukey test was applied to compare means. The effect of treatments was assessed by regression analysis. Data statistic analysis was performed with the system of variance analysis for balanced data (Sisvar) version 4.2 (FERREIRA, 1999).

\section{Irrigation}

Treatments started 16 days after sowing. Volumes of water replacement in deficit irrigation treatments were obtained through the percentile of water evapotranspirated (consumed) by the control treatment, which received 100\% of replacement water. To manage control treatment irrigation we used the equation of water balance: ET $=\mathrm{I}-\mathrm{D}$, in which ET is the evapotranspiration (volume of consumed water, $\left.\mathrm{ml} \mathrm{pot}^{-1}\right)$, I is the volume of applied water $\left(\mathrm{ml} \mathrm{pot}^{-1}\right)$ and D is the volume of drained water $\left(\mathrm{ml} \mathrm{pot}^{-1}\right)$.

\section{RESULTS AND DISCUSSION}

During the experiment, maximum and minimum temperatures observed were $33.8^{\circ} \mathrm{C}$ and $15.3^{\circ} \mathrm{C}$ (mean $21.9^{\circ} \mathrm{C}$ ), respectively, and average humidity was $69 \%$. Greenhouse temperature during rapeseed development remained within the range recommended for the crop, 12$30^{\circ} \mathrm{C}$ (CANOLA COUNCIL OF CANADA, 2003).

\section{Water management}

Table 1 shows the volumes of water applied in each treatment. It is observed that until the beginning of treatments, which started 16 days after sowing, all plants received the same volume of water, 1.91 plant $^{-1}$. Later, the volume applied was proportional in each treatment: plants with $0 \%$ of water deficit received 28.21 plant $^{-1}$ during application of treatments; plants with $30 \%$ of water deficit received 19.61 plant $^{-1}$; and plants with $60 \%$ of water deficit received 11.2 plant $^{-1}$.

\section{Analysis of vegetative parameters}

Table 2 shows the summary of results of variance analysis for crop vegetative parameters. Significant differences is observed in the following variables: volume of water applied (1 plant $\left.{ }^{-1}\right)$, (stem diameter $(\mathrm{mm})$, number of branches, number of leaves and number of pods. However, there were no significant differences between treatments in the variable plant height $(\mathrm{cm})$.

Table 1 - Volume of water applied in each treatment. UNIKASSEL, Witzenhausen, Hessen, 2009.

\begin{tabular}{|c|c|c|c|}
\hline \multirow{3}{*}{ Treatment } & Volume of water & Volume of water & Total volume \\
\hline & $\begin{array}{l}\text { applied until the beginning of } \\
\text { treatments }\end{array}$ & applied during treatments & of applied water \\
\hline & \multicolumn{3}{|c|}{ 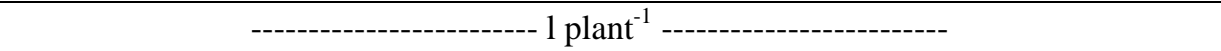 } \\
\hline $0 \%$ of deficit & 1.9 & 28.2 & 30.1 \\
\hline $30 \%$ of deficit & 1.9 & 19.6 & 21.5 \\
\hline $60 \%$ of deficit & 1.9 & 11.2 & 13.1 \\
\hline
\end{tabular}

Table 2 - Variance analysis of volume of water applied $\left(1\right.$ plant $\left.^{-1}\right)$, plant height $(\mathrm{cm})$, stem diameter (mm), number of branches, number of leaves and number of pods regarding different levels of water deficit applied during rapeseed development. UNIKASSEL, Witzenhausen, Hessen, 2009.

\begin{tabular}{cccccccc}
\hline \multirow{2}{*}{ FV } & GL & \multicolumn{7}{c}{ QM } \\
\cline { 3 - 8 } & $\begin{array}{c}\text { Volume of water } \\
\text { applied }\left(1 \text { plant }{ }^{-1}\right)\end{array}$ & $\begin{array}{c}\text { Plant } \\
\text { Height }(\mathrm{cm})\end{array}$ & $\begin{array}{c}\text { Stem } \\
\text { diameter }(\mathrm{mm})\end{array}$ & $\begin{array}{c}\text { Number of } \\
\text { branches }\end{array}$ & $\begin{array}{c}\text { Number } \\
\text { of leaves }\end{array}$ & $\begin{array}{c}\text { Number } \\
\text { of pods }\end{array}$ \\
\hline Treatments & 2 & $1446.6^{*}$ & $664.86^{\mathrm{ns}}$ & $90.65^{*}$ & $151.66^{*}$ & $1081.05^{*}$ & $186114.05^{*}$ \\
Residue or error & 57 & 1.91 & 323.31 & 2.63 & 13.70 & 302.51 & 11129.11 \\
CV (\%) & 0.00 & 15.30 & 12.39 & 37.91 & 36.50 & 29.81 \\
Mean & 21.66 & 117.53 & 13.10 & 9.76 & 47.65 & 353.85 \\
\hline
\end{tabular}

in which: $\mathrm{ns}$ - non significant by $\mathrm{F}$ test at 5\% probability; * - significant by $\mathrm{F}$ test at 5\% probability; FV: variation factor; GL: degree of freedom; QM: mean square; CV: variance coefficient. 
Significant differences for volume of water applied can be explained by the application: the treatment with $60 \%$ water deficit received a water volume equivalent to $43.5 \%$ evapotranspiration, whereas the one with $30 \%$ water deficit received a volume equivalent to $71.4 \%$ evapotranspiration. Consequently, such decrease in volume of water applied should explain the significant decrease in crop vegetative parameters.

Sangtarash et al. (2009) verified rapeseed response in two irrigation regimes: daily irrigation to keep soil at field capacity and irrigation when plants showed symptoms of water deficit. The authors concluded that water deficit caused decrease in plant height, stem diameter and total dry matter. Taylor et al. (1991) assessed the effect of irrigation on yield components of rapeseed crop, verifying that water deficit significantly affected number of pods per $\mathrm{m}^{2}$. A similar result was found by Confalone e Dujmovich (1999) when studying the effect of water deficit on soybean crop. The authors verified that number of pods was the yield component mostly affected by water deficit.

Figures 1-4 show regression analysis for rapeseed vegetative parameters. The assessed variables showed linear response in relationship with the water deficit applied.

Maximum diameter of middle stem was verified in the treatment with $0 \%$ of water deficit $(15.45 \mathrm{~mm})$. Later there was decrease of $0.0692 \mathrm{~mm}$ plant $^{-1}$ for each unit change in water deficit. Maximum average number of branches was verified in the treatment with $0 \%$ of water deficit (11.6). Later, there was decrease of 0.0833 branches plant $^{-1}$ for each unit change in water deficit.

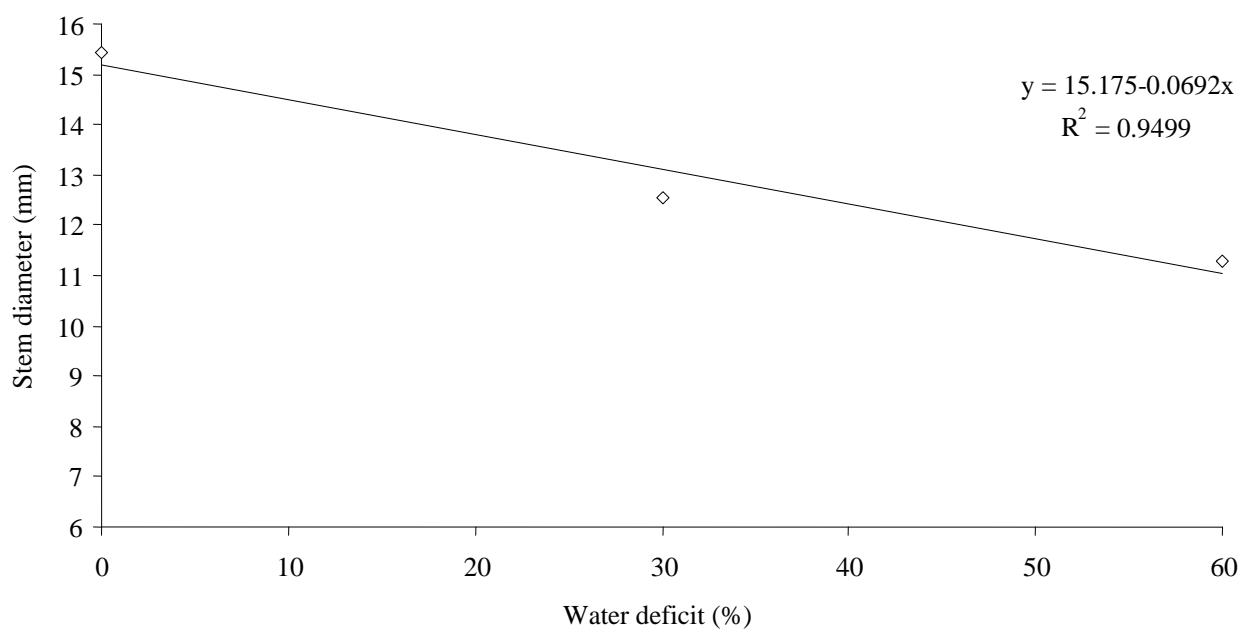

Figure 1 - Effect of water deficit on rapeseed stem diameter (mm).UNIKASSEL, Witzenhausen, Hessen, 2009.

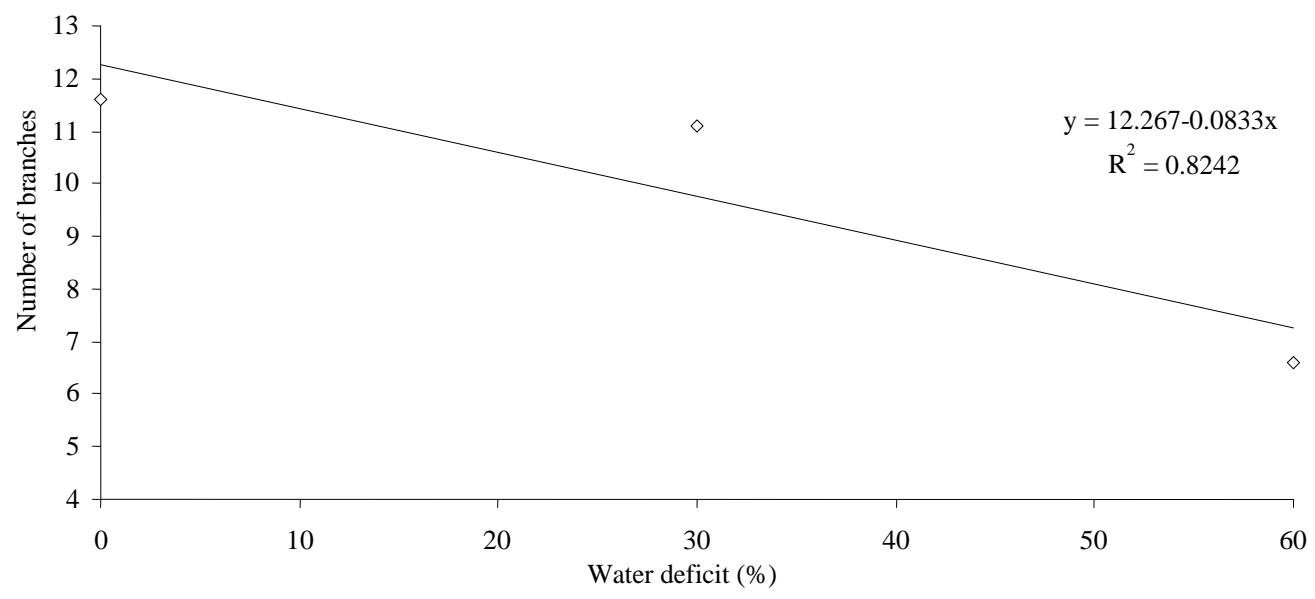

Figure 2 - Effect of water deficit on number of rapeseed branches UNIKASSEL, Witzenhausen, Hessen, 2009. 
Maximum average number of leaves was observed in the treatment with $0 \%$ of water deficit (55.1). Later, there was decrease of 0.245 leaves plant ${ }^{-1}$ for each unit change in water deficit. Maximum average number of pods was observed in the treatment with $0 \%$ of water deficit (451.9). Later, there was decrease of 3.21 pods plant $^{-1}$ for each unit change in water deficit.

Variance analysis for total green matter and total dry matter in each treatment is shown in Table 3. Significant differences for the assessed variables by $\mathrm{F}$ test at $5 \%$ of probability. Were observed.

Figure 5 and Figure 6 show regression analysis for total green matter and total dry matter. The assessed variables showed linear response in relation to the water deficit applied.

Maximum total average green matter was observed in the treatment with $0 \%$ of water deficit ( 285.3 grams plant $\left.^{-1}\right)$. Later, there was decrease of 2.25 grams plant $^{-1}$ for each unit change in water deficit. Maximum total average dry matter was observed in the treatment with $0 \%$ of water deficit $\left(51.25\right.$ grams plant $\left.^{-1}\right)$. Later, there was decrease of 0.33 grams plant $^{-1}$ for each unit change in water deficit. Such result can be explained by decrease in the volume of water applied to treatments, corresponding to evapotranspiration deficit. Similar results were found by Frizzone (1995) and Banuelos et al. (2002).

\section{Analysis of grain yield}

Table 4 shows a summary of variance analysis data for grain yield (grams plant ${ }^{-1}$ ) when crop was submitted to different levels of water deficit. According to the results, there were significant differences between treatments.

Decrease in crop yield can be explained by decrease in the volume of water applied to treatments, corresponding to evapotranspiration deficit, which significantly reduced number of pods and grain yield.

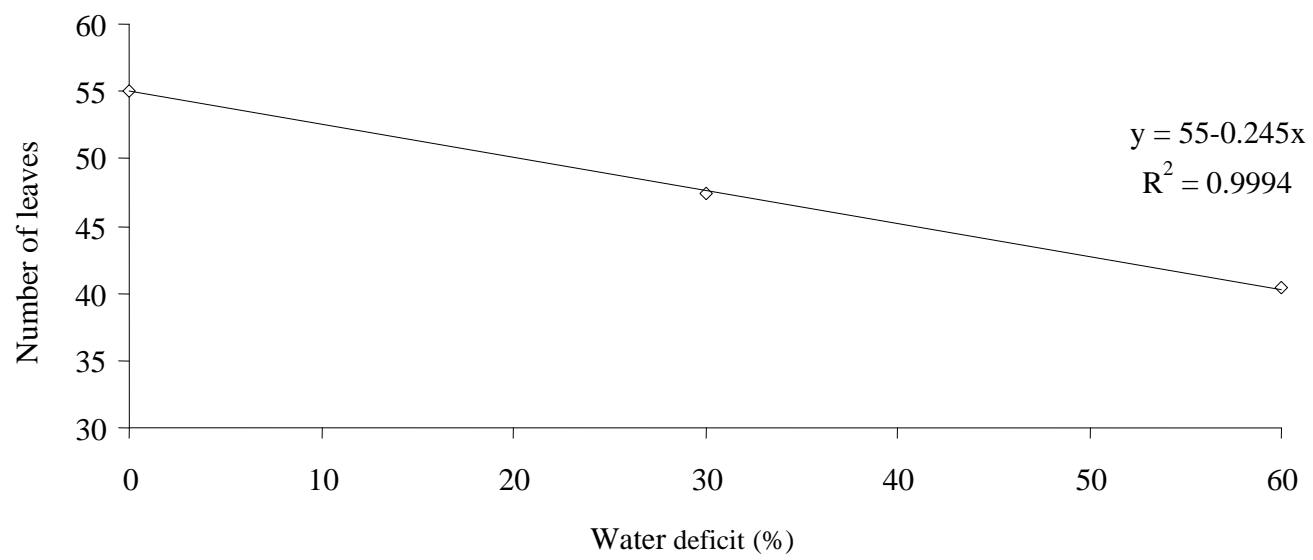

Figure 3 - Effect of water deficit on number of rapeseed leaves. UNIKASSEL, Witzenhausen, Hessen, 2009.

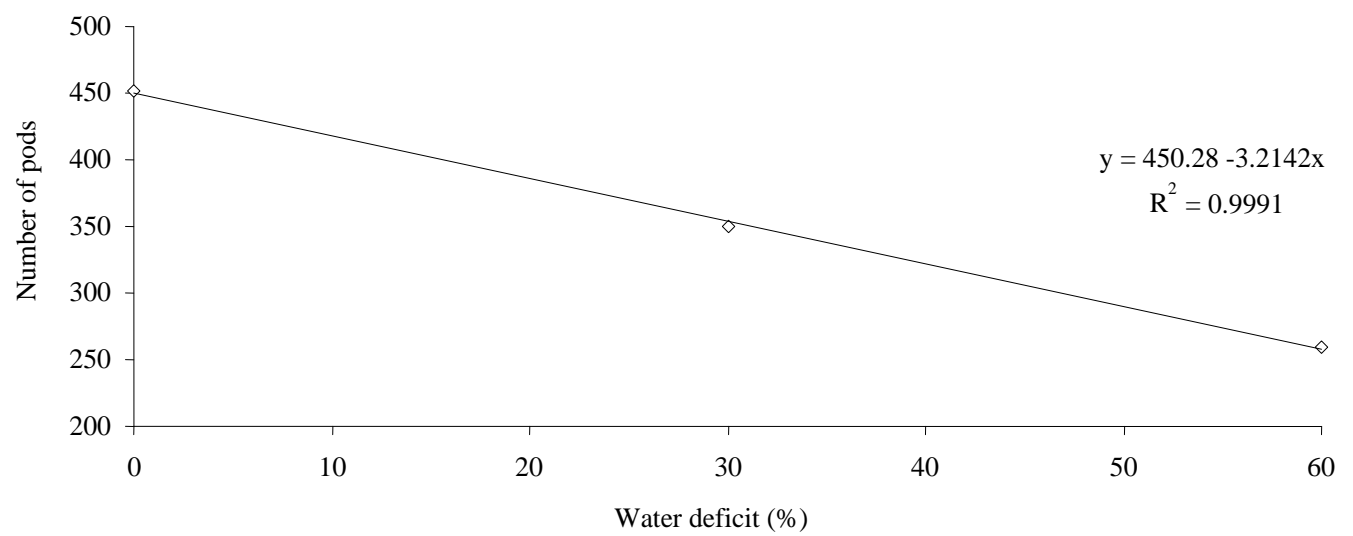

Figure 4 - Effect of water deficit on number of rapeseed pods. UNIKASSEL, Witzenhausen, Hessen, 2009. 
Table 3 - Variance analysis of total green matter $\left(\mathrm{g} \mathrm{plant}^{-1}\right)$ and total dry matter $\left(\mathrm{g} \mathrm{plant}^{-1}\right)$ under different levels of water deficit applied during development of rapeseed crop. UNIKASSEL, Witzenhausen, Hessen, 2009.

\begin{tabular}{|c|c|c|c|}
\hline \multirow{3}{*}{ FV } & \multirow{3}{*}{ GL } & \multicolumn{2}{|c|}{$\mathrm{QM}$} \\
\hline & & Total green matter & Total dry matter \\
\hline & & \multicolumn{2}{|c|}{------------- grams plant ${ }^{-1}$------------ } \\
\hline Treatments & 2 & $91789.65^{*}$ & $1962.21 *$ \\
\hline Residue or error & 57 & 1159.57 & 28.74 \\
\hline $\mathrm{CV}(\%)$ & - & 15.84 & 12.91 \\
\hline Mean & - & 214.95 & 41.53 \\
\hline
\end{tabular}

in which: ns - non significant by $\mathrm{F}$ test at $5 \%$ probability; * - significant by $\mathrm{F}$ test at $5 \%$ probability; FV: variation factor; GL: degree of freedom; QM: mean square; CV: variance coefficient.

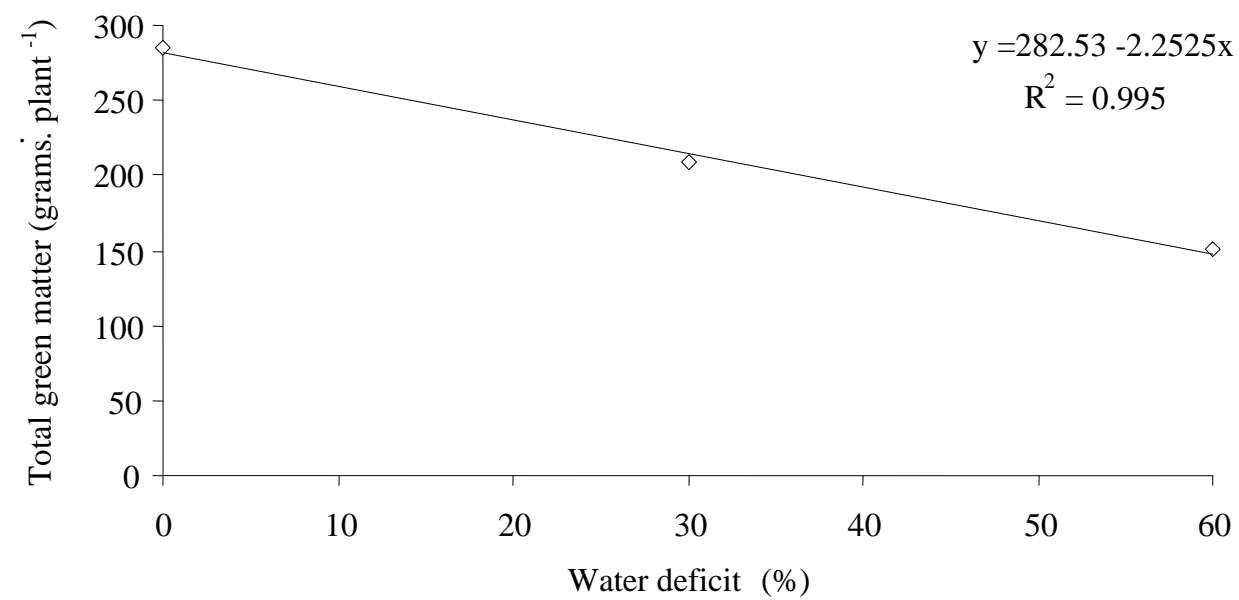

Figure 5 - Effect of water deficit on total green matter of rapeseed crop. UNIKASSEL, Witzenhausen, Hessen, 2009.

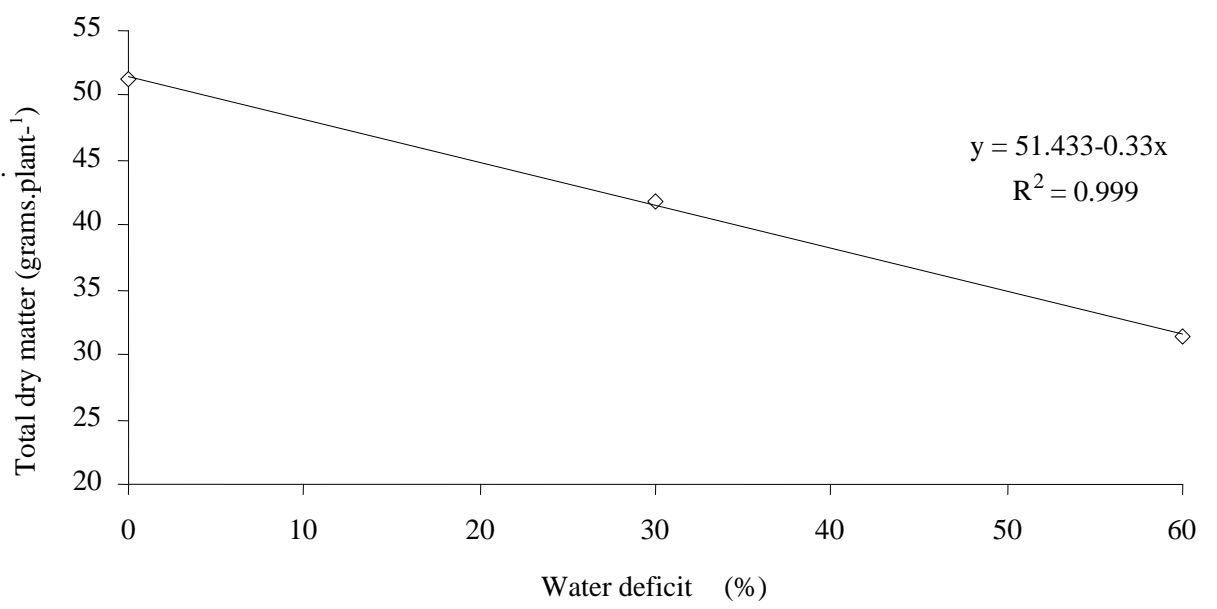

Figure 6 - Effect of water deficit on total dry matter of rapeseed crop. UNIKASSEL, Witzenhausen, Hessen, 2009. 
Table 4 - Variance analysis of grain yield (grams plant $\left.{ }^{-1}\right)$ regarding different levels of water deficit applied during development of rapeseed crop. UNIKASSEL, Witzenhausen, Hessen, 2009.

\begin{tabular}{ccc}
\hline FV & GL & QM \\
\cline { 3 - 3 } & & Grain yield $\left(\right.$ grams plant $\left.^{-1}\right)$ \\
\hline Treatments & 2 & $222.14^{*}$ \\
Residue or error & 57 & 5.19 \\
CV $(\%)$ & - & 28.87 \\
Mean & - & 7.89
\end{tabular}

in which: $\mathrm{ns}-$ non significant by $\mathrm{F}$ test at $5 \%$ probability; $*$ significant by $\mathrm{F}$ test at $5 \%$ probability; $\mathrm{FV}$ : variation factor; GL: degree of freedom; QM: mean square; CV: variance coefficient.

Regression analysis for grain yield is shown in Figure 7 . We verified that grain yield showed linear response in relation to the water deficit applied.

Maximum grain yield was observed in the treatment with $0 \%$ of water deficit $\left(10.74\right.$ grams plant $\left.^{-1}\right)$. Later, there was decrease of 0.1085 grams plant $^{-1}$ for each unit change in water deficit.

\section{Analysis of grain quality}

Table 5 shows the effect of different levels of water deficit on grain quality with the summary of variance analysis for protein content (\%) and oil content (\%) of rapeseed grain.

There was a significant difference for oil content between treatments. Protein content, however, showed no significant change.

Decrease in rapeseed oil content was also assessed by Sinaki et al. (2007) in an experiment carried out in Iran. The authors verified significant decrease in grain oil content in nonirrigated treatments. Similar results were found by Bouchereau et al. (1996), who assessed the effect of water deficit on rapeseed protein and oil content in a greenhouse experiment carried out in France. The authors verified significant decrease in oil content and increase in protein content.

Maehler et al. (2003) assessed grain quality of two soybean cultivars regarding soil water availability by performing two treatments, with and without irrigation. The

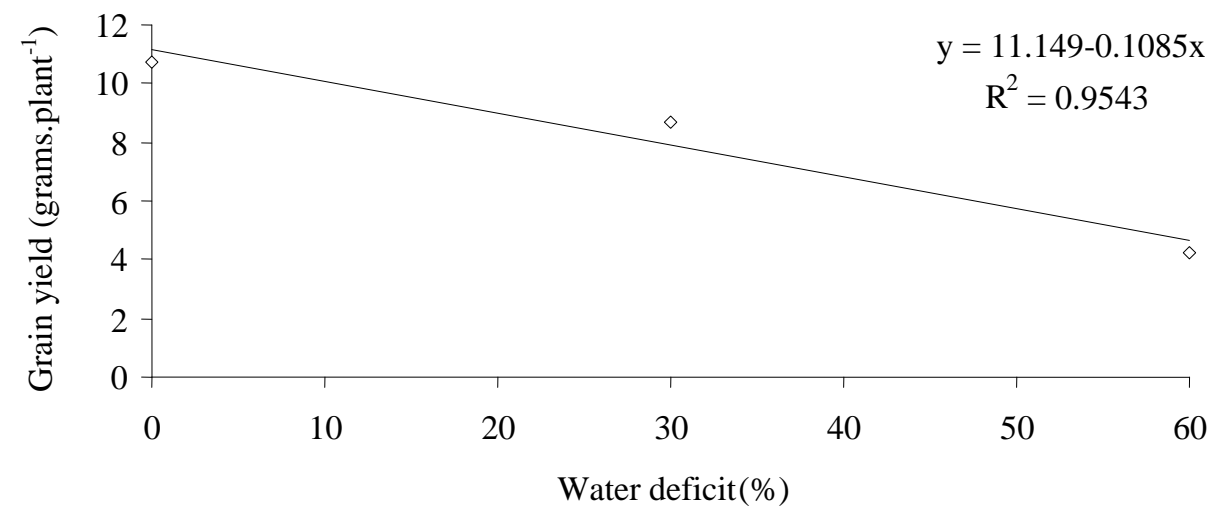

Figure 7 - Effect of water deficit on grain yield of rapeseed crop. UNIKASSEL, Witzenhausen, Hessen, 2009.

Table 5 - Variance analysis of grain protein content (\%) and grain oil content (\%), regarding different levels of water deficit applied during development of rapeseed crop. UNIKASSEL, Witzenhausen, Hessen, 2009.

\begin{tabular}{cccc}
\hline FV & GL & & QM \\
\cline { 3 - 4 } & & Protein content $(\%)$ & Oil content $(\%)$ \\
\hline Treatments & 2 & $17.76^{\mathrm{ns}}$ & $96.70^{*}$ \\
Residue or error & 57 & 17.092 & 29.67 \\
CV $(\%)$ & & 5.16 & 6.03 \\
Mean & & 29.33 & 37.75 \\
\hline
\end{tabular}

in which: $\mathrm{ns}$ - non significant by F test at 5\% probability; * - significant by F test at 5\% probability; FV: variation factor; GL: degree of freedom; QM: mean square; CV: variance coefficient. 
authors observed increase of $39 \%$ in grain yield and protein content of irrigated soybean, but no significant differences in oil content. in Figure 8.

Regression analysis for grain oil content is shown

Maximum average oil content of grain was observed in the treatment with $0 \%$ of water deficit, $39.57 \%$. Later, there was decrease of $0.0709 \%$ in oil content for each unit change in water deficit.

According to Bouchereau et al. (1996), decrease in oil concentration in rapeseed grain exposed to water deficit is justified by changes in availability of precursors to fulfil the grain, as reproductive organs and grains are built of resources either recently achieved or previously amassed in the vegetative part. This could have happened in the experiment, as number of leaves, green matter and dry matter significantly decreased according to the treatments, which could have led to a decrease in oil content.

\section{Analysis of rapeseed sensitivity to water deficit}

\section{Sensitivity to water deficit in rapeseed vegetative parameters}

Table 6 shows the percentile decrease of stem diameter, number of branches, number of leaves, number of pods, total green matter, total dry matter, grain yield and grain oil content of rapeseed according to each water deficit applied.

The treatment with $30 \%$ of deficit shows total green matter reduction $(27 \%)$ as the most sensitive to water deficit, followed by number of pods $(22 \%)$, grain yield (19\%), total dry matter (18\%), number of leaves (14\%), grain oil content $(8 \%)$, number of branches $(4 \%)$ and stem diameter $(2 \%)$.

The treatment with $60 \%$ of water deficit shows decrease namely in grain yield, $60 \%$ when compared to the control plant, followed by total green matter (47\%), number

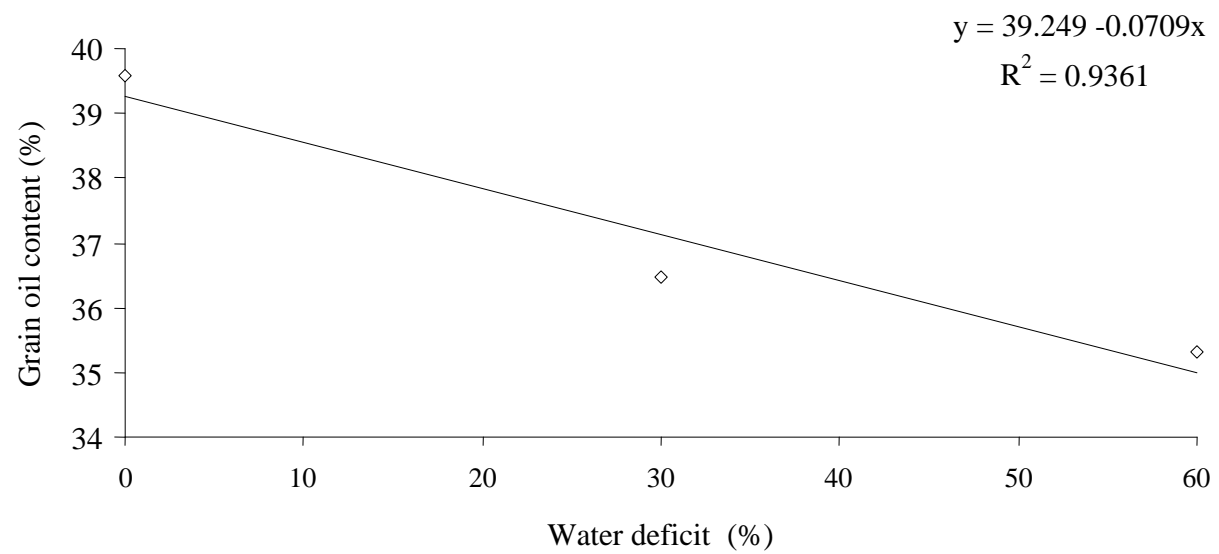

Figure 8 - Effect of water deficit on grain oil content of rapeseed crop. UNIKASSEL, Witzenhausen, Hessen, 2009.

Table 6 - Relationship between water deficit applied and decrease in vegetative parameters (\%), grain yield and grain oil rate of rapeseed. UNIKASSEL, Witzenhausen, Hessen, 2009.

\begin{tabular}{cccc}
\hline Assessed parameters & \multicolumn{3}{c}{ Water deficit applied } \\
\cline { 2 - 4 } & $0 \%$ & $30 \%$ & $60 \%$ \\
\hline Stem diameter (mm) & $0 \%$ & $2 \%$ & $48 \%$ \\
Number of branches & $0 \%$ & $4 \%$ & $27 \%$ \\
Number of leaves & $0 \%$ & $14 \%$ & $26 \%$ \\
Number of pods & $0 \%$ & $22 \%$ & $47 \%$ \\
Total green matter & $0 \%$ & $27 \%$ & $39 \%$ \\
Total dry matter & $0 \%$ & $18 \%$ & $60 \%$ \\
Grain yield & $0 \%$ & $19 \%$ & $11 \%$ \\
Grain oil content & $0 \%$ & $8 \%$ & \\
\hline
\end{tabular}


of branches (43\%), total dry matter (39\%), number of leaves $(27 \%)$, stem diameter (18\%) and grain oil content (11\%), respectively.

Water deficit of $60 \%$ decreased all assessed parameters, owing to water deficit amassment since the beginning of treatments, as shown in Figures 9-12.

Figures 13 and 14 show relative fall of vegetative parameters, grain yield and oil content of rapeseed grain according to the water deficit applied. The indicator of crop sensitivity to water deficit, ky, was lower than one for all assessed variables, which shows that crop sensitivity to water deficit is proportionally lower than the water deficit applied.
Grain yield was the parameter most sensitive to water deficit, ky of 0.934 (Figure 14), followed by total green matter, ky of 0.809 (Figure 14); total dry matter, ky of 0.6367 (Figure 14); number of branches, ky of 0.6034 (Figure 13); number of pods, ky of 0.4976 (Figure 13); stem diameter, ky of 0.4833 (Figure 13); number of leaves, ky of 0.4483 (Figure 13); and oil content, ky of0.1954 (Figure 14).

Decrease in grain yield owing to water deficit in rapeseed crop was also verified by other authors, such as Taylor et al. (1991), Bouchereau et al. (1996), Champolivier e Merrien (1996) and Sinaki et al. (2007), thus corroborating our findings.

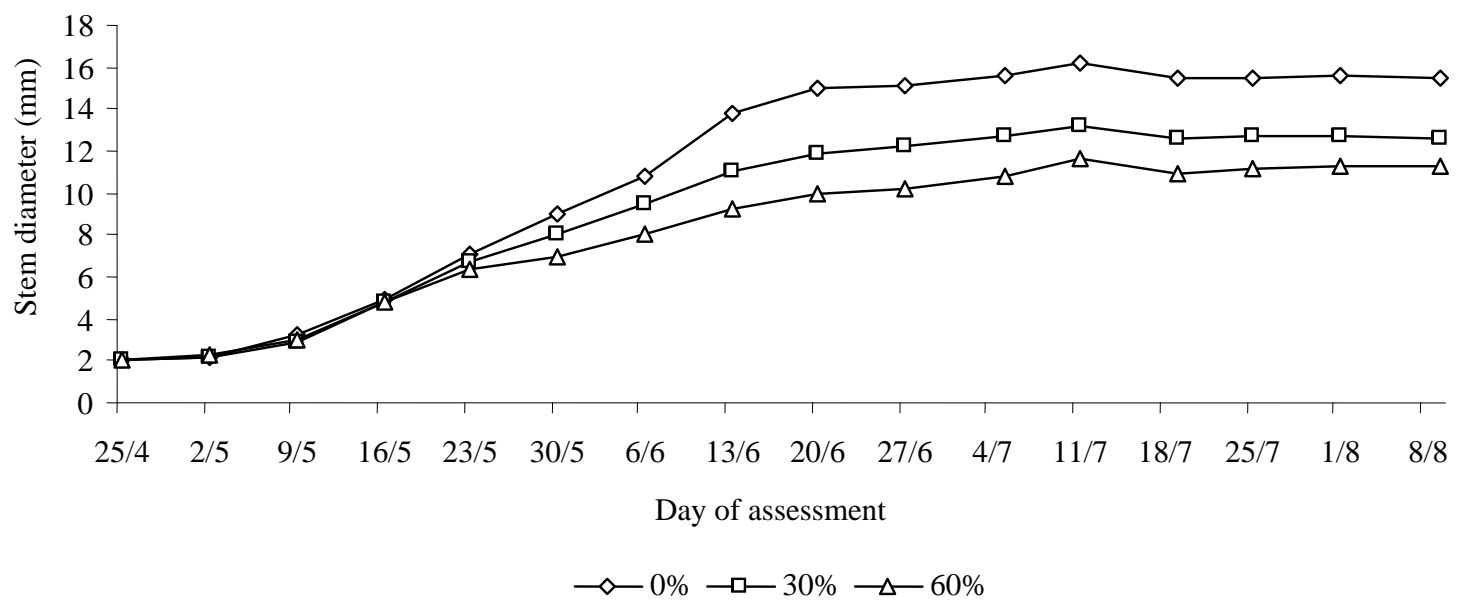

Figure 9 - Effect of water deficit on stem diameter during development of rapeseed crop. UNIKASSEL, Witzenhausen, Hessen, 2009

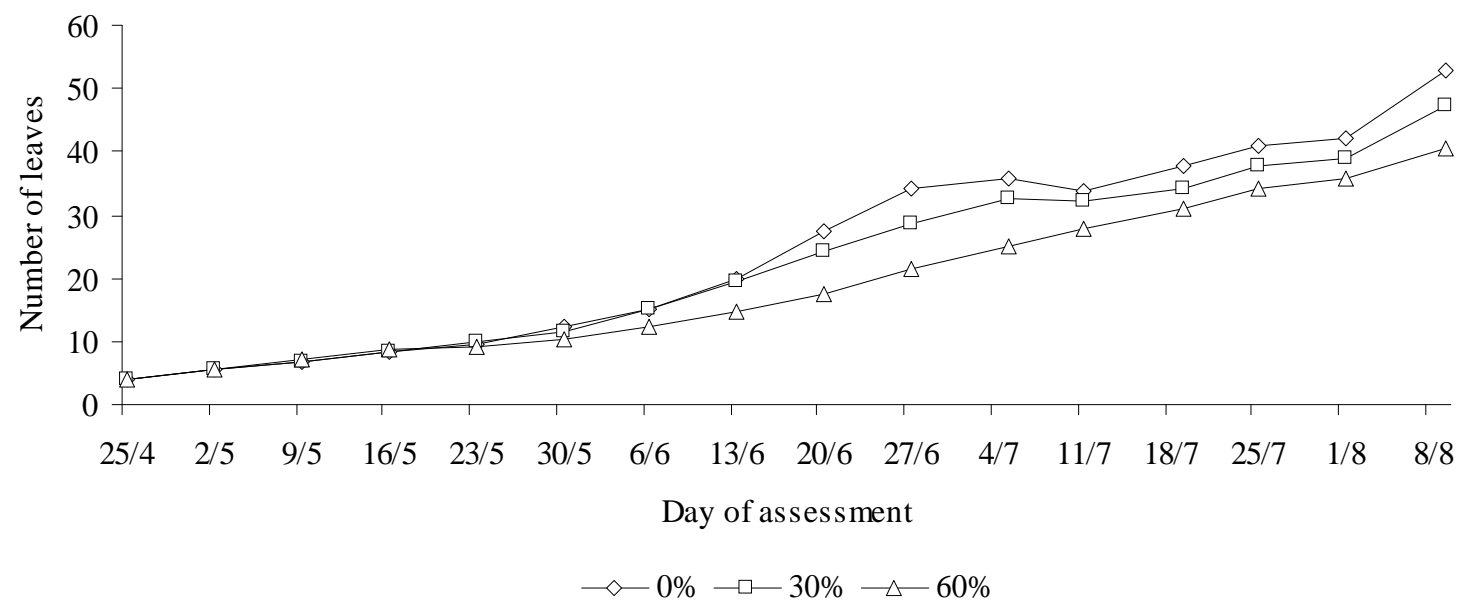

Figure 10 - Effect of water deficit on number of leaves during development of rapeseed crop. UNIKASSEL, Witzenhausen, Hessen, 2009. 
Payero et al. (2008) assessed the effect of different levels of water deficit in corn crop in Nebraska (USA), finding the yield factor of response, ky, of 1.58. Oktem (2008) assessed yield sensitivity of sweet corn in Turkey, applying water deficit from $10 \%$ to $30 \%$ evaporation of class A tank, finding yield factor of response to water deficit from 0.82 to 1.43. Calvache et al. (1997) achieved bean factor of response (ky) of 2.2 when water deficit occurred during fulfilment of pods, proving this is the period of highest crop sensitivity to water deficit.

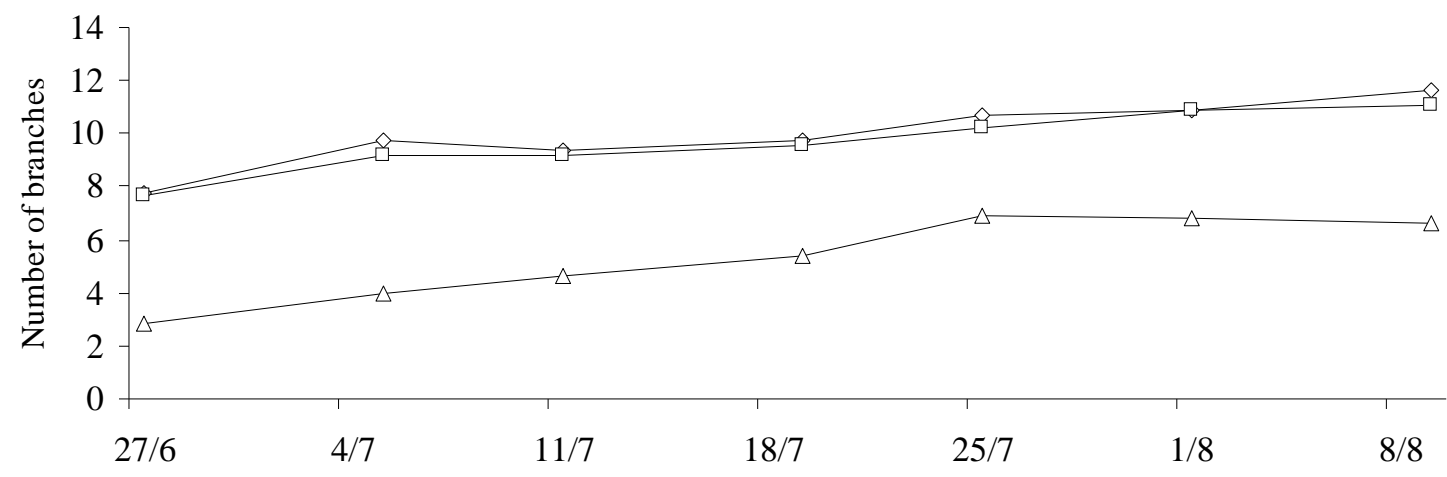

Day of assessment

$\neg-0 \% \multimap-30 \% \multimap-60 \%$

Figure 11 - Effect of water deficit on number of branches during development of rapeseed crop. UNIKASSEL, Witzenhausen, Hessen, 2009.

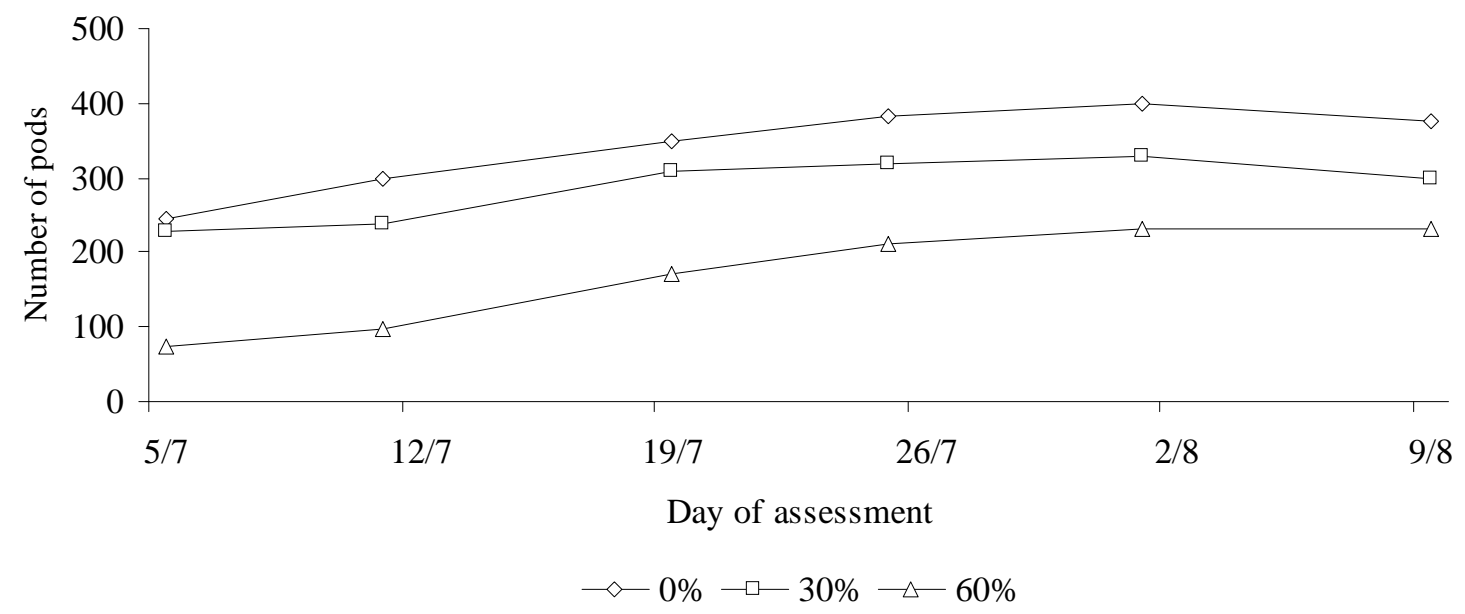

Figure 12 - Effect of water deficit on number of pods during development of rapeseed crop. UNIKASSEL, Witzenhausen, Hessen, 2009. 


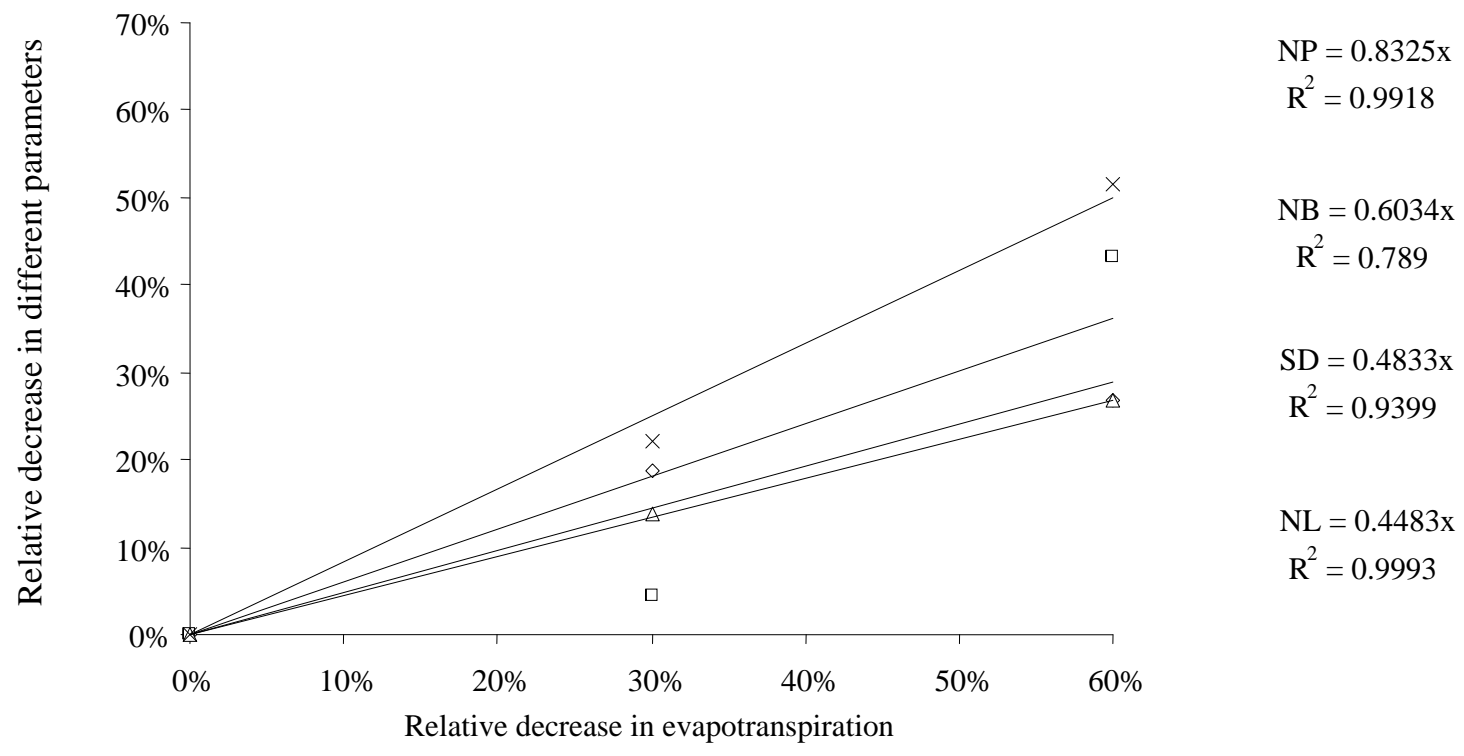

$\diamond$ Stem diameter (SD) $\square$ Number of branches (NB) $\triangle$ Number of leaves (NL) $\times$ Number of pods (NP)

Figure 13 - Relative decrease in stem diameter, number of branches, number of leaves and number of pods according to relative decrease in evapotranspiration in rapeseed crop. UNIKASSEL, Witzenhausen, Hessen, 2009.

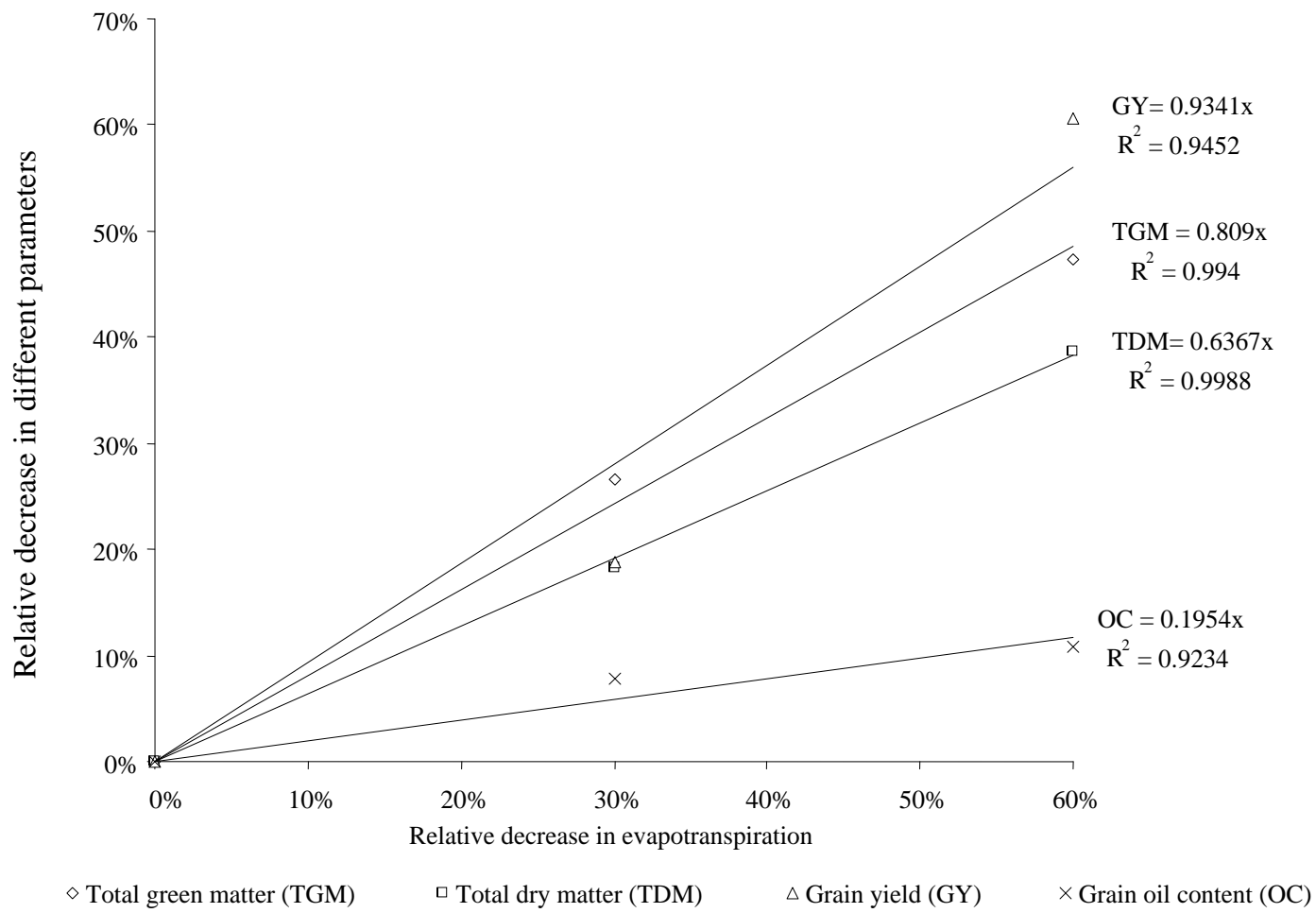

Figure 14 - Relative decrease in total green matter, total dry matter, grain yield and grain oil content according to relative decrease of evapotranspiration in rapeseed. UNIKASSEL, Witzenhausen, Hessen, 2009. 


\section{CONCLUSIONS}

Irrigation deficit decreases all aspects of growth parameters, with major reductions in levels of $60 \%$ of water deficit.

The relationship between fall of relative yield and relative evapotranspiration deficit (ky) was lower than one for all analysed variables, showing that the assessed factors decrease less than the percentile decrease of applied water.

Grain yield showed high sensitivity to water deficit, proving that irrigation can definitely benefit crop grain yield.

\section{ACKNOWLEDGEMENTS}

Department of Agricultural Engineering of Kassel University, Germany; Department of Agricultural Engineering of the University of Lavras, Brazil; National Council for Scientific and Technological Development, CNPq, Brazil. Foundation for Research Support of the State of Minas Gerais, FAPEMIG.

\section{REFERENCES}

ARABHOSSEINI, A. et al. Modeling of thin layer drying of tarragon (Artemisia dracunculus L.). Industrial Crops and Products, Amsterdam, v.29, n.1, p.53-59, 2009.

BANUELOS, G.S.; BRYLA, D.R.; COOK, C.G. Vegetative production of kenaf and canola under irrigation in central California. Industrial Crops and Products, Amsterdam, v.15, p.237-245, May 2002.

BERNARDO, S.; SOARES, A.A.; MANTOVANI, E.C. Manual de irrigação. 6.ed. Viçosa, MG: UFV, 625p, 2006.

BOUCHEREAU, A. et al. Water stress effects on rapeseed quality. European Journal of Agronomy, Amsterdam, v.5, n.1, p.19-30, 1996.

CALVACHE, A.M. et al. Efeito da deficiência hídrica e da adubação nitrogenada na produtividade e na eficiência do uso de água em uma cultura do feijão. Scientia Agricola, Piracicaba, v.54, n.3, p.232-240, 1997.

\section{CANOLA COUNCIL OF CANADA. Canola growers} manual. Ottawa, 2003. Disponível em: <http:// 'Www.canolacouncil.org/canola growers_manual.aspx Acesso em: 20 jun. 2008.

CHAMPOLIVIER, L.; MERRIEN, A. Effects of water stress applied at different growth stages to Brassica napus L. var. oleifera on yield, yield components and seed quality. European Journal of Agronomy, Paris, v.5, n.3/4,p.153-160, 1996.

CONFALONE, A.; DUJMOVICH, M.N. Influência do déficit hídrico sobre o desenvolvimento e rendimento da soja. Revista Brasileira de Agrometeorologia, Santa Maria, v.7, n.2, p.183-187, 1999.

\section{CORDEIRO, L.A.M. Avaliação de características} agronômicas e qualidade de sementes de canola (Brassica napus L. var. oleifera) cultivada em Viçosa, MG. Viçosa, MG: UFV, 1997. 103p.

DETAR, W.R. Yield and growth characteristics for cotton under various irrigation regimes on sandy soil.

Agricultural Water Management, Amsterdam, v.95, n.1, p.69-76, 2008.

DOORENBOS, J.; KASSAN, A.H. Efeito da água no rendimento das culturas. Campina Grande: UFPB, 1994. 306p.

FARRE, I.; FACI, J.M. Comparative response of maize (Zea mays L.) and sorghum (Sorghum bicolor L. Moench) to deficit irrigation in a Mediterranean environment. Agricultural Water Management, Amsterdam, v.83, n.5, p.135-143, 2006.

FERREIRA, D.F. Sistema para análise de variância para dados balanceados - SISVAR. Lavras: UFLA, 1999.

FRIZZONE, J.A. Lâminas de água e doses de nitrogênio na produção de aveia (Avena sativa L.) para forragem. Scientia Agricola, Piracicaba, v.52, n.3, p.578-586, 1995.

GEERTS, S.; RAES, D. Deficit irrigation as an on-farm strategy to maximize crop water productivity in dry areas. Agricultural Water Management, Amsterdam, v.96, n.9, p.1275-1284, 2009.

KHAN, S.; HANJRA, M.A.; MU, J. Water management and crop production for food security in China: a review. Agricultural Water Management, Amsterdam, v.96, n.3, p.349-360, 2009.

MAEHLER, A.R. et al. Qualidade de grãos de duas cultivares de soja em função da disponibilidade de água no solo e arranjo de plantas. Ciência Rural, Santa Maria, v.33, n.2, p.213-218, mar./abr. 2003. 
OKTEM, A. Effect of water shortage on yield, and protein and mineral compositions of drip-irrigated sweet corn in sustainable agricultural systems. Agricultural Water Management, Amsterdam, v.95, n.9, p.1003-1010, 2008.

PAYERO, J.O. et al. Effect of irrigation amounts applied with subsurface drip irrigation on corn evapotranspiration, yield, water use efficiency, and dry matter production in a semiarid climate. Agricultural Water Management, Amsterdam, v.95, n.8, p.895-908, 2008.

PAYERO, J.O.; MELVINY, R.S.; IRMAK, S.; TARKALSON, D. Yield response of corn to deficit irrigation in a semiarid climate. Agricultural Water Management, Amsterdam, v.84, p.101-112, July 2006.

RIJSBERMAN, F.R. Water scarcity: fact or fiction? Agricultural Water Management, Amsterdam, v.80, p.522, Feb. 2006.

SANGTARASH, M.H. et al. Differential sensitivity of canola (Brassica napus) seedlings to ultraviolet-B radiation, water stress and abscisic acid. Environmental and Experimental Botany, Elmsford, v.66, n.2, p.212-219, 2009.

SINAKI, J.M.et al. The effects of water deficit during growth stages of canola (Brassica napus L.). American-
Eurasian Journal of Agricultural \& Environmental Science, Alexandria, v.2, n.4, p.417-422, 2007.

TAYLOR, A.J.; SMITH, C.J.; WILSON, I.B. Effect of irrigation and nitrogen fertilizer on yield, oil content, nitrogen accumulation and water use of canola (Brassica napus L.). Fertilizer Research, Copenhagen, v.29, n.3, p.249-260, 1991.

TOMM, G.O. Indicativos tecnológicos para produção de canola no Rio Grande do Sul. Passo Fundo: Embrapa, 2007. 32p.

WANG, Z.; SUN, J.; LIAO, X.; CHEN, F.; ZHAO, G.; WU, J.; HU, X. Mathematical modeling on hot air drying of thin layer apple pomace. Food Research International, Barking, v.40, n.1, p.39-46, 2007.

ZHANG, B.; LI, F.; HUANG, G.; CHENG, Z.; ZHANG, Y. Yield performance of spring wheat improved by regulated deficit irrigation in an arid área. Agricultural Water Management, Amsterdam, v.79, n.1, p.28-42, 2006.

ZWART, S.J.; BASTIAANSSEN, W.G.M. Review of measured crop water productivity values for irrigated wheat, rice, cotton and maize. Agriculture Water Management, Amsterdam, v.69, n.2, p.115-133, 2004. 